\title{
Методика определения клиновидности плоскопараллельной пластинки (в дополнение к методике настройки микросканера на базе плоскопараллельной пластинки)
}

\author{
Р.А. Гладков, И.И. Кремис. \\ Филиал ИФП СО РАН «КТИПМ», Новосибирск, 630090, просп. Лаврентьева, 2/1 \\ тел: (383) 330-91-06, эл. почта: igor21738@ngs.ru
}

DOI 10.34077/RCSP2019-176

Настройка микросканера (MC) на базе плоскопараллельной пластинки (ППС) требует учёта клиновидности. Вклад в смещение проекции внешней сцены паразитным оптическим клином, может оказаться больше чем вклад, который могла бы дать идеальная плоскопараллельная пластинка при прочих равных условиях. Значение сдвига вносимого клином зависит от точности изготовления ППС. Если производитель и уложился в допуски при производстве пластинки, итоговое значение клиновидности каждого германиевого стекла необходимо считать отдельно не сводя клиновидность к погрешности расчётов. Как показал опыт настройки, клиновидность ППС модно считать погрешностью, в пределах 5\%, при смещении проекции до 100 мкм, если клиновидность стекла составляет менее 10 секунд. Технологически изготовить такое изделие может не каждое специализированное оборудование. Именно по этой причине определение клиновидности необходимо рассматривать как отдельную процедуру. В видимом диапазоне волнового спектра, для определения угла клиновидности ППС, используется интерференционные методы. В ИК диапазоне, практически доступных, эффективных методов нет.

Предлагается методика определения угла клина германиевой пластинки. Привлекательность метода состоит в простоте процедур измерения и доступности оборудования.

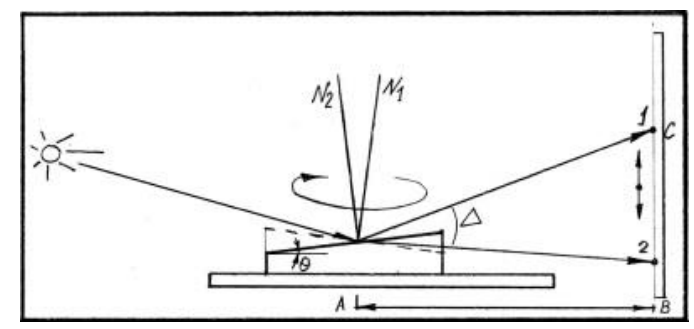

Рис. 1

Измерительный стенд схематично изображен на рис.1. В его состав входят: диодный лазер; экран для фиксации положения следа луча; подложка из оконного стекла; германиевая пластинка; рулетка для замера расстояния от экрана до середины германиевого стекла.

Все вычисления проводятся в отражённом свете. На устойчивую поверхность горизонтально устанавливается подложка (степень горизонтальности не критична). На подложку кладётся германиевая пластинка и обводится маркером. Направив в середину ППС луч лазера (точка А), на экране получим след. Вращение германиевой пластинки, без выхода за отмеченную маркером границу, приводит к колебанию следа лазера из самого высокой точки 1 в самую низкую точку 2 и обратно. Замерим расстояние АВ (порядка 10 метров) и интервал между точками 1 и 2 . Допустим, что треугольник $\mathrm{ABC}$ прямоугольный. После проведения несложных преобразований угол клиновидности $\theta$ будет равен:

$$
\theta=\frac{1}{4} \operatorname{arctg} \frac{\mathrm{CB}}{\mathrm{AB}}
$$

Метод позволяет получить приемлемую точность при его использовании в рамках методики настройки микросканера. Относительная погрешность в смещении проекции сцены, при использовании данных о клине полученных изложенным методом, не превышает $10 \%$.

\section{Литература}

[1] Кузнецов С.И.// Краткий справочник по физике часть 3. Издательство Томского политехнического университета, 2013. 